\title{
Comunidades Eclesiais de Base e Teologia da Libertação: algumas reflexões sobre catolicismo liberacionista e ritual
}

\author{
Fabrício Roberto Costa* \\ Arnaldo José Zangelmi** \\ Reinaldo Azevedo Schiavo ${ }^{* * *}$
}

Resumo: As Comunidades Eclesiais de Base (CEBs) foram e, em muitos contextos, ainda são muito influentes na motivação dos fiéis católicos para a luta política. Muitos deles se tornaram militantes de referência em movimentos sociais, sindicatos, partidos políticos e associações de moradores. As idéias de conscientização, democratização e organização são elementos fundamentais para os agentes pastorais engajados no trabalho das CEBs. Nosso objetivo é mostrar que outras perspectivas menos ativistas também ocupam lugar nestes grupos. Esse artigo se pautará pela análise de trabalhos de cunho antropológico que revelam que, apesar do enfático trabalho de "conscientização" promovido por dioceses e pastorais católicas alinhadas ao discurso liberacionista, a maioria da população é pouco ativa e desinteressada em movimentos sociais ou em política partidária. Assim, consideramos que o ajustamento dos atores sociais às suas experiências de vida e contextos locais faz com que haja um descompasso entre o que desejavam os agentes pastorais e intelectuais católicos engajados com as idéias liberacionistas e a forma com que os fiéis participantes das CEBs compreendem e respondem às mensagens da "campanha cultural" católica na prática cotidiana.

Palavras-chave: Comunidade Eclesial de Base, Teologia da Libertação, Catolicismo

Abstract: The Ecclesial base communities (CEBs) were and, in many contexts, still are very influent in the motivation of Catholic believers to the political struggle. Many of them became reference militants in social movements, labor unions, political parties and neighborhood associations. The ideas of raising awareness, democratization and organization are fundamental elements to the Pastoral agents engaged in the work of the CEBs. Our goal is to show that the less activist perspectives also occupy an important

\footnotetext{
* Doutorando em Ciências Sociais pela Universidade Federal Rural do Rio de Janeiro.

${ }^{* *}$ Mestre em Extensão Rural.

${ }^{* * *}$ Mestrando em História pela UFOP
}

INTRATEXTOS, Rio de Janeiro. vol 2, nº 1, pp 33 - 50, 2010. 
place in these groups. This paper will analyze the works conducted with an Anthropologic approach which reveals that, although the emphatic work of "raising awareness" promoted by dioceses or Catholic pastorals aligned to the liberationist discourse, most of the population is less active and non-interested in social movements or political parties politics. Therefore, we consider that the social actors' adjustment to their life experience and local contexts provoke a disharmony among what the Pastoral agents and Catholic intellectuals engaged with the liberationist Catholicism desire and the way the believers of the CEBs comprehend and respond to the Catholic "cultural campaign" messages in the everyday practice.

Keywords: Comunidade Eclesial de Base, Teologia da Libertação, Catolicismo

\section{Introdução}

As Comunidades Eclesiais de Base (CEBs) têm uma importância histórica muito significativa no Brasil. As consequências sociais e políticas destes grupos vinculados à teologia da libertação ${ }^{1}$ são muito relevantes. As CEBs são caracterizadas por Burdick (1998), como sendo "congregações Católicas nas quais o clero e os agentes pastorais estão engajados, de uma forma ou de outra, em esforços para despertar a consciência política e social "(p. 11).

Para ele, o aspecto mais marcante das CEBs é a presença dos grupos de reflexão, nos quais, com ajuda dos manuais ou pequenos folhetins católicos, e às vezes com ajuda de um agente pastoral, os "membros lêem a Bíblia juntos, discutem suas implicações no que diz respeito ao dia-a-dia de suas vidas, e são inspirados tanto na direção da justiça social quanto por ela mesma”. (BURDICK, 1998, p. 11).

As CEBs são consideradas unidades muito importantes para a divulgação das idéias da teologia da libertação. Segundo Burdick (1998), muitos têm considerado esta mobilização católica como o mais revolucionário movimento católico desde a Reforma:

\footnotetext{
${ }^{1}$ Em boa parte das CEBs, a legitimidade e inspiração teológica eram buscadas na teologia da libertação, segundo a qual deve haver uma necessária relação entre a teologia e contextos socioeconômicos. Essa assertiva corrobora com a "opção pelos pobres" cujo postulado é que "embora Deus ame igualmente os pobres e os ricos, favorece os pobres em sua luta pela libertação das estruturas opressoras do capitalismo, criados pelos ricos" (THEIJE, 2002, p. 23). Assim, é postulado importante na teologia da libertação o fato de que a salvação "deve ser encontrada nesta vida: não é um prêmio a ser obtido após a morte" (ibid, p. 23).
}

INTRATEXTOS, Rio de Janeiro. vol 2, nº 1, pp 33 - 50, 2010. 
Contrariamente à Igreja pré-conciliar, a ortodoxia pós-Vaticano II declara que Deus não sente necessidade de testar o amor de Seus Filhos, nem de exigir que se provem pela via crusis. Os católicos pós-conciliares, portanto, seguem um passo adiante da relutância pré-conciliar em falar do mau olhado, e de questionar sua realidade. Na visão pré-conciliar, pessoas malévolas manipulam as forças do mal e pessoas fracas sucumbem a elas; para o católico pós-conciliar, Deus não permite que tais forças testem Seus filhos (BURDICK, 1998, p. 36).

Assim, "enquanto o católico pré-conciliar se volta para Deus numa atitude de submissão e auto-renúncia, o católico pós-conciliar aprende a ver Deus trabalhando pela liberdade humana" (BURDICK, 1998, p. 36). Os padres vinculados a esta mobilização religiosa "têm pregado o Evangelho como uma exigência de justiça social e da democratização da autoridade religiosa" (p. 11). Neste sentido,

os teólogos da libertação argumentam que as profecias tanto do Velho quanto do Novo Testamento prometem um Reino no qual a humanidade viverá em paz, igualdade e justiça, e, como profetizado no Apocalipse, que este Reino será realizado não no céu, mas na Terra. Além disso, como Deus usou Moisés para libertar Seu povo, assim também Ele estabelecerá Seu Reino com a assistência da ação humana. Esta é a razão pela qual os liberacionistas declaram que cabe à Humanidade a iniciativa de lutar por este Reino (BURDICK, 1998, p. 11).

O Concílio Vaticano II (1962 - 65) foi o acontecimento que, a nível mundial, desencadeou essa leva de renovações eclesiásticas, "abrindo as portas" da Igreja de Roma à modernidade e proporcionando novas formas de eclesialidade a partir da realidade das Igrejas particulares. Segundo um padre e também sociólogo,

a nível da Igreja Universal, o acontecimento maior foi a inesperada primavera que a convocação do Concílio provocou, florescendo em caminhos de ecumenismo e diálogo com as demais religiões e os não-crentes, em aggiornamento da vida e das estruturas pastorais da Igreja, de seu serviço ao mundo e de sua reflexão teológica (BEOZZO, 1993, p 07).

INTRATEXTOS, Rio de Janeiro. vol 2, nº 1, pp 33 - 50, 2010. 
Na América Latina, os ecos conciliares soaram através da Conferência Episcopal de Medellín (1968), onde a Igreja latino-americana teria consolidado sua "opção preferencial pelos pobres" a partir de uma teologia voltada para a realidade do continente configurada por uma expressiva desigualdade social proporcionada pelo sistema capitalista que por aqui se desenvolveu. Tendo como tema: Presença da Igreja na Atual Transformação da América Latina, essa Conferência fomentou um novo modelo de catolicismo preocupado com os problemas sócio-políticos e, ao mesmo tempo, deu legitimidade a uma nova forma de organização.

Esta era pautada na formação de Comunidades Eclesiais de Base, cuja atuação propiciou a proliferação e consolidação das propostas da teologia da libertação. Elas foram fundadas no Brasil a partir da década de 1960, "visando suprir a carência de ministros ordenados, constituíram o lugar de um processo de conscientização dos cristãos em face dos problemas sociais e eclesiais" (REGIDOR, 1996, p. 27).

As CEBs, por meio da organização dos leigos, das reflexões acerca do cotidiano e dos problemas diários tendo como referência a bíblia, além do apoio de padres e bispos para a mobilização popular, acabaram gerando e/ou apoiando vários movimentos sociais por todo o país, tanto no meio urbano quanto no rural. Em geral, os intelectuais vinculados à Igreja Católica atribuem à Instituição boa parte dos ganhos dos movimentos populares (LESBAUPIN, 2000; LESBAUPIN et allii, 2004; OLIVEIRA, 2001; PETRINI, 1984; RODRIGUES, 1997; TEIXEIRA, 1996).

Theije alerta-nos para o fato de muito já ter sido pesquisado nas ciências sociais sobre essas comunidades e serem várias as ambigüidades sobre o tema. "A falta de uma definição inequívoca do assunto provoca a discordância e a confusão sobre o impacto das comunidades de base no Brasil” (2002, p. 47). Como critério analítico, essa autora faz uma reflexão separada dos termos que compõem esta sigla, a fim de identificar a discordância existente sobre esse conceito. Assim, comunidade refere-se ao localismo dos grupos e ao caráter coletivo de sua organização. Eclesial está relacionado à principal motivação do grupo: a fé. Já a palavra base conforma-se como o principal ponto de desencontro entre os autores. Alguns (LÖWY, 1995) a utilizam no sentido marxista, referindo-se aos pobres e 
oprimidos, outros (MAINWARING, 1989) usam o termo para se referir tanto aos agentes pastorais quanto às CEBs.

Também é comum, entre os autores, a não definição do conceito, subentendendo que todos já sabem o que significa. Assim, não dá para simplificar CEBs em um modelo único. Isso se deve "em parte por causa da falta de consenso sobre a definição das próprias CEBs" (BURDICK, 1998, p. 12). Além disso, "as comunidades, obviamente, variam de tamanho dependendo da população da vizinhança ou da cidade na qual estejam situadas" (ibid, p. 12). Vale ressaltar também que, apesar do conceito ter sido lapidado em função da opção preferencial pelos pobres, nem sempre ele é usado para definir grupos politicamente engajados, de militantes sociais ou comunidades pobres.

No Brasil, principal expoente da "igreja dos pobres" na América Latina², vários foram os leigos, religiosos, padres, bispos e teólogos que assimilaram o novo discurso católico e aderiram a esse projeto, seja na organização de CEBs pelos confins do país, seja na articulação de sindicatos e movimentos sociais, ou mesmo na produção de uma vasta literatura militante sobre a Teologia da Libertação.

O movimento que se baseia ideologicamente nesta perspectiva teológica, em geral é conhecido como progressista. Theije (2002) considera que o significado político do termo "progressista", torna inadequada a análise que propõe. Assim, prefere a expressão catolicismo liberacionista, para se referir ao movimento que tem embasamento ideológico na Teologia da Libertação.

Esse movimento liberacionista não obteve sucesso contínuo e regular nas diversas paróquias brasileiras. Em alguns contextos, bispos e padres tinham resistências a este movimento católico e o dificultava de diversas maneiras. Já em outros havia dificuldades dos católicos internalizarem e agirem em consonância com as novas propostas.

\footnotetext{
${ }^{2}$ A Igreja Católica do Brasil, dentre as demais latino-americanas, foi a que melhor implementou o modelo de catolicismo da igreja dos pobres, pelo menos na década de 1970. Até os anos de 1980, quando o Vaticano desencadeou fortes investidas para conter os avanços desse modelo de catolicismo, as diretrizes e orientações hegemônicas da CNBB orientavam-se pelos pressupostos da teologia da libertação, incentivando a formação de CEBs e dando forte suporte à organização das pastorais sociais. Uma analise mais aprofundada sobre a assimilação da igreja dos pobres pela Igreja no Brasil encontra-se em Mainwaring (1989) e Theije (2002).
}

INTRATEXTOS, Rio de Janeiro. vol 2, nº 1, pp 33 - 50, 2010. 
O que vamos fazer neste texto é concentrarmos em algumas situações concretas da vida social que funcionavam como empecilhos para o crescimento e consolidação dos ideais liberacionistas e das Comunidades de Base. Faremos uma abordagem a respeito da dissonância entre teoria e prática das CEBs, refletindo sobre algumas experiências e apresentando trabalhos que consideramos referências importantes e emblemáticas a respeito do catolicismo liberacionista no Brasil, quais sejam o trabalho de Mariz (1994), Burdick (1998) e Theije (2002). Para concluir o lançaremos algumas hipóteses e argumentos a respeito das dificuldades de concretização dos ideais deste movimento católico, bem como faremos as considerações finais.

\section{As CEB's na prática: refletindo sobre algumas experiências}

Não são raras as situações em que as CEBs foram de extrema importância para a constituição de uma variedade de lutas por justiça social e incentivaram a formação de lideranças políticas de esquerda. Elas foram influentes na motivação dos fiéis católicos para a luta política, muitos deles se envolveram em organizações comunitárias, movimentos sociais pela reforma agrária, sindicatos e partidos políticos. Neste sentido, "alguns escritores têm afirmado que o discurso liberacionista é inerentemente persuasivo para os participantes da comunidade e portanto os têm arrastado a todos para a luta política" (BURDICK, 1998, p. 14).

Entretanto, outras perspectivas menos ativistas também ocupam lugar importante no trabalho das CEBs. Burdick (1998) cita, como exemplo, uma pesquisa realizada na cidade de Vitória - ES, cuja diocese realizou trabalho de pastoral progressista durante mais de vinte anos. O levantamento de informações com "70 000 membros ativos das CEBs revelou que a maioria permanecia desinteressada em movimentos sociais ou outros assuntos políticos" (ibid, p. 14). Há, então, um descompasso relevante entre o que desejavam os agentes pastorais e intelectuais católicos engajados com as ideias liberacionistas e a forma com que os fiéis católicos, participantes das CEBs, compreenderam e responderam às mensagens da "campanha cultural"” católica.

\footnotetext{
${ }^{3}$ Segundo Theije (2002, p. 72) "o objetivo de toda campanha de política cultural é mudar as ideias, os sentimentos e a prática do povo". No catolicismo, "ao longo das épocas, diferentes grupos de atores realizaram campanhas culturais com o objetivo de estabelecer ideologias e práticas religiosas específicas"
}

INTRATEXTOS, Rio de Janeiro. vol 2, nº 1, pp 33 - 50, 2010. 
Dessa forma, uma questão começa a se mostrar muito evidente nos resultados práticos dos propósitos liberacionistas: para uma mesma teoria e projeto para as CEBs há uma grande diversidade de formas de existência na prática. Hewitt (apud BURDICK, 1998, p. 20) afirma que podem ser encontrados seis tipos de CEBs, variando de grupos devocionais puramente apolíticas até aqueles que têm iniciativas extremamente engajadas com o aumento da conscientização e ativismo político dos católicos. Burdick, caracterizando as CEBs encontradas em seu estudo na Baixada Fluminense, as vê como tendo consciência despertada, todavia não estão geralmente engajadas em atividades e movimentos sociais que não dizem respeito às práticas católicas.

As reflexões de Sahllins (1990) contribuem para compreendermos as formas como as mensagens recebidas são rearticuladas nas práticas culturais locais. Ele demonstra como a cultura é reordenada no processo histórico, superando a tradicional dicotomia entre estrutura e ação. Sahllins enfatiza que os atores sociais repensam os esquemas que recebem, os submetem a "riscos empíricos", construindo o significado em cada prática específica, em "Ilhas de história".

Nesse sentido, concordamos também com Canclini ao refletir sobre as interações culturais como "processos de hibridação", nos quais a heterogeneidade cultural está na interação "dos poderes oblíquos que misturam instituições liberais e hábitos autoritários, movimentos sociais democráticos e regimes paternalistas, e as transações de uns com os outros" (2006, p. 19). Assim, se pode perceber como as mensagens liberacionistas se relacionaram com os contextos locais e possibilitaram a construção de significados imprevistos tanto pela comunidade quanto pelos desencadeadores desse projeto mais amplo.

Destacamos também o trabalho de Theije (2002) que estudou as CEBs da Diocese de Garanhuns-PE e percebeu que as ideias liberacionistas chegavam e em boa parte das vezes eram compreendidas, mas a prática das mesmas acontecia em raras ocasiões. Para ela, uma das explicações é que as ideias são sempre mediadas no plano local, e naquele contexto, a violência, as relações de dependência com os grupos patronais e o poder

(ibid, p. 118). É dentro desta perspectiva que vemos a difusão das ideias da teologia da libertação como sendo uma campanha liberacionista.

INTRATEXTOS, Rio de Janeiro. vol 2, nº 1, pp 33 - 50, 2010. 
consolidado de muitos políticos conservadores dificultavam os leigos de colocar em prática as ideias da Teologia da Libertação.

Na Diocese, todos sabiam que a "Igreja não podia proteger os leigos da violência social ou política de seus opositores, nem suprimir a dependência dos pobres em relação aos poderosos da sociedade local. Os líderes leigos tinham plena consciência disso" (THEIJE, 2002, p. 291). Também chegou a conclusão de que "a análise dos resultados concretos da campanha liberacionista mostrou que a maioria das ações religiosas consiste em reprodução e continuidade" (Ibid, p. 349).

Mariz (1994), no mesmo sentido, percebeu que muitas das ideias propostas pelas CEBs, como por exemplo a democratização de base das práticas católicas, eram difíceis de serem colocadas em práticas, pois na vida cotidiana isso tem limites e problemas. Os objetivos propostos pelos liberacionistas nem sempre tinham contexto apropriado para a prática. Theije chegou à conclusão que sempre há um processo de 'ajuste situacional' às mensagens religiosas, ou seja, os atores sociais pensam e refletem sobre as mensagens religiosas dentro de seus contextos para agir ou não conforme as ideias recebidas, pois podem ocorrer diversos impedimentos locais para tais ações. Assim, ela acredita que considerar a não ação política como uma falha de conscientização do projeto liberacionista seria "uma má compreensão do funcionamento do processo político e um descaso do raciocínio do povo" (2002, p. 333).

As dificuldades apontadas levam em conta as práticas sociais comuns dos brasileiros, bem como suas condições estruturais. E é neste sentido que é preciso reconhecer que os desafios assumidos pelas CEBs eram enormes, sobretudo na tentativa de introduzir novas formas de pensar que estavam distantes das práticas culturais estabelecidas ao longo do processo da formação social brasileiro. Falar de democracia radical, de relações horizontais entre homens e mulheres, padres e leigos eram ideias que estavam distantes da realidade cotidiana dos fiéis católicos do Brasil, sobretudo dos pobres.

Para Mariz (1994) a mudança na visão de mundo proposta pelos liberacionistas requer comprometimento com a ética social na esfera pública. O que se propunha, então, era um trabalho de educação popular, cujo objetivo era que as pessoas assumissem uma visão de mundo que as levasse à busca da formação de uma sociedade mais justa. Assim, 
Mariz (1994) acredita que as CEBs procuram mudar pressupostos cognitivos da visão de mundo das camadas pobres da população, que em consequência deveriam assumir uma nova forma de definição da realidade.

Nesta nova definição, embasada na nova leitura das concepções bíblicas, o plano de Deus se refere antes à comunidade, aos pobres ou à Humanidade do que à vida privada do indivíduo. Dessa forma, as CEBs destacam o papel da sociedade na transformação da trajetória histórica da humanidade e, diferentemente dos pentecostais, não ressaltam a moral pessoal nem a transformação dos indivíduos isoladamente no processo de concretização do plano de Deus, a ênfase é dada ao combate do pecado social, que consiste em estruturas injustas. A luta contra as injustiças é uma luta religiosa e a luta religiosa é social. As CEBs falam pouco do pecado individual (MARIZ, 1994).

Burdick (1998), neste sentido, fala das concepções do Padre Cosme, um liberacionista que acreditava que o católico deveria ser consciente e chegar à conclusão de que pecados como adultério, prostituição, roubo, dentre outros, devem ser colocados no contexto dos pecados sociais mais amplos, como a desigualdade, a injustiça e a opressão de classes. Na visão de Cosme, os católicos conscientes não poderiam permanecer satisfeitos em ver a miséria como fenômeno isolado, mas reconhecer o papel da sociedade na criação desta situação, bem como o papel que teria o cristão no sentido de transformá-la. Para fazer com que os seus paroquianos assumissem isso de forma mais consistente, o padre investiu na idéia de que parassem "de pedir perdão pelos pecados individuais e, ao invés, fazer penitência em confissões públicas semanais, durante a Missa, por pecados como omissão em ajudar os jovens abandonados, esquecimento dos sem-terra ou sem-pão, egoísmo e falta de fraternidade" (Ibid, p. 39).

Esse tipo de prática certamente gerava embaraços na forma de pensar dos fiéis. Era uma mudança bastante radical para pessoas acostumadas a confessar seus pecados com os párocos. As pessoas tinham alívio emocional com estas confissões e estavam perdendo essa oportunidade pela forma mais politizada e racionalizada que o padre vinha assumindo. Em muitos contextos, os padres engajados com as concepções liberacionistas encontravam algumas dificuldades de inserção de novas ideias no lugar daquelas mais tradicionais, em função disso se viam em situações inusitadas. 
Mariz (1994) narra o fato ocorrido com um padre que trabalha com CEBs e encontrou dificuldades em abençoar uma criança doente a pedido dos pais que acreditavam que, dessa forma, a criança poderia ser curada mais rapidamente. Para o padre, a benção não tinha utilidade de resolver um problema de saúde, todavia a maioria dos fiéis acreditava mais na benção do que nos recursos científicos. Assim, o padre que tinha uma visão bastante racionalista e secular, num contexto em que os católicos tinham formas bem diferentes de lidar com a situação, também precisava passar por um "ajuste situacional" nas suas práticas.

Na visão liberacionista assumida pelas CEBs, Deus praticamente não lança mão de milagres para ajudar os seres humanos a realizar seus projetos. O que Deus precisa é dos homens para realizar seu plano, espera deles a ação e confia em suas habilidades de transformar o mundo, sem dispor do sobrenatural (MARIZ, 1994). Burdick (1998), no mesmo sentido, cita as concepções do Padre Ancieto que temia que a crença das pessoas em "mau-olhado" tirasse dos indivíduos a responsabilidade moral que tinham em suas ações. Para isso, Ancieto identificava o demônio ao egoísmo, à falácia, e à cobiça.

\footnotetext{
Ou, como explicou um iniciado do cursilho: 'Se eu sempre dissesse que eu sempre agi mal porque o diabo me induziu a este procedimento, isto não seria mais que fugir da responsabilidade'. Era no solo fértil deste compromisso da responsabilidade humana que a visão católica progressista cresceria mais tarde (BURDICK, 1998, p. 36).
}

Assim, a religião ia assumindo uma proposta cada vez mais racionalizada e politizada, enveredando cada vez mais pelos dilemas do social. Uma questão importante que se levanta é como ficam os rituais diante de tal contexto? Para Mariz (1994), na concepção adotada pelos agentes pastorais da Teologia da Libertação, os rituais são apenas símbolos para lembrar uma verdade e/ou princípios éticos. Isso rompe com uma concepção mágica de religião, que vê na repetição do ritual, o ponto mais importante da prática religiosa.

Neste sentido, Mariz (1994) cita Frei Betto que descreveu algumas experiências em que se procurou adaptar os rituais e símbolos do catolicismo à cultura do pobre brasileiro INTRATEXTOS, Rio de Janeiro. vol 2, nº 1, pp 33 - 50, 2010. 
substituindo a consagração do pão por consagração de cuscuz. Para ela, o efeito provável dessa experiência era o desencantamento dos símbolos e rituais. Um relato seguindo essa mesma concepção é citado por Burdick, segundo ele

\footnotetext{
Um exemplo de máxima dramaticidade deste tipo de nivelamento ocorreu na festa do dia de Nossa Senhora. Tradicionalmente, o acontecimento do dia era a cerimônia da coroação de uma estatueta de Maria. Cosme convocou os fiéis locais para substituir a estátua pela mulher mais idosa que morasse no bairro. Isto foi, para algumas pessoas, a última gota. 'Nunca vi nada como isso!' reclamou uma mulher. 'Quando eles colocaram aquela velha como Nossa Senhora! Não se devia fazer uma coisa dessas! O povo não deveria coroar seres humanos, eles não são suficientemente puros. E aquela mulher foi uma macumbeira! Transformar um ser humano numa imagem! Tudo errado! Nunca vi nada assim...Não consegui voltar lá' (1998, p. 159).
}

Dada a importância do ritual para as práticas católicas, alguns consideravam que os humanos não eram suficientemente puros para receberem tal homenagem e tinham dificuldade em lidar com as novas concepções de vida religiosa. Padre Ancieto, por exemplo, se opunha à adoração, algo muito arraigado no catolicismo popular. Ele encorajava "os frequentadores da igreja que pretendessem fazer peregrinações aos santuários, ao invés disso, fazerem doações locais à caridade. 'Desse jeito' ele dizia, 'vocês estão realmente agradando ao santo. O santo quer que você o imite"”. (BURDICK, 1998, p. $37)$.

Outra ruptura proposta pelas CEBs em teoria, que nem sempre se mostrou consistente na prática, é a idéia de uma relação mais horizontal, portanto menos hierárquica tanto na vida social, como também na religiosa. Assim, defende-se maior participação de todos nas decisões, e questiona o próprio valor da obediência aos líderes quando esses tomarem decisões sem consultar os membros do grupo (MARIZ, 1994).

Não obstante a concepção democratizante da teologia da libertação e das CEBs, “o poder do padre liberacionista permanece amplo. Assim Cosme mantém o controle sobre a consagração da hóstia, e influencia cada detalhe da liturgia, a programação e objetivos a 
curto e a longo prazos da comunidade" (BURDICK, 1998, p. 40). Muitas vezes "quando ele convoca encontros consultivos, quase sempre (como de bom grado admitiu pra mim) ele está simplesmente apresentando para confirmação de posições já formadas em nível da diocese" (Ibid, p. 40).

Burdick (1998) cita outro caso paradigmático que envolveu algumas lideranças religiosas da comunidade de São Jorge, na Baixada Fluminense. Mário e Rosana eram lideranças importantes da Igreja Católica local. Mário formou a Congregação Mariana local seguindo os passos de seu pai que era uma liderança importante da mesma em Minas Gerais. Mário também liderou a construção de uma capela local, a qual foi diretor por mais de duas décadas. "Em 1982, todavia, o novo padre insistiu em que ele provasse a sua liderança numa eleição livre. Após a sua derrota por uma chapa apoiada pelo padre, ele deixara de participar da Igreja local" (p. 27).

Esse é um exemplo de prática de democracia radical que acabou promovendo a perda de uma liderança fundamental para a história daquela paróquia, bem como uma divisão entre os que apóiam uma chapa ou a outra. No interior das CEBs, muitas vezes procura-se uma democratização das relações sociais, é um lugar em que todos têm o direito da fala, da opinião e de dar sugestões. A idéia é importante e não duvidamos que ela funcione e tenha funcionado em diversos contextos, todavia, em muitos outros, essa pretensa igualdade esbarra na diferença de habilidade argumentativa dos membros, bem como no fato da Igreja Católica ser hierárquica e não ser disposta a abrir mão desta característica.

A habilidade dos agentes pastorais, de expor e convencer as pessoas, é maior que a dos membros das CEBs. Essa assimetria leva a que, embora todas as propostas e decisões sejam submetidas à votação, nem sempre são explicitadas como propostas ou colocadas em votação todas as questões e interesses presentes no grupo (MARIZ, 1994). Para Theije, muitas das idéias e objetivos colocados eram complicados para o povo, que muitas vezes ficava perdido em meio a muitas argumentações. Segundo ela, "a maioria teve pouca educação e não aprendeu a raciocinar da maneira abstrata e racional como o clero faz" (2002, p. 246).

INTRATEXTOS, Rio de Janeiro. vol 2, nº 1, pp 33 - 50, 2010. 
A exigência dos agentes pastorais e alguns leigos, de que as lideranças das CEBs sejam participativas e coerentes em suas práticas, levou alguns membros a se sentirem pressionados e se afastarem por não se sentirem capazes de corresponder a estas expectativas. A necessidade de um pensamento coerente e racional, de acordo com os pressupostos liberacionistas, também é fator de dificuldade para a maioria dos membros. Muitas ocasiões exigiam certas habilidades dos agentes pastorais e muita disposição dos leigos, já que o processo poderia ser longo e desânimos de lado a lado não deve ter sido algo incomum.

Para Theije "o discurso sobre a luta social e o conflito de classes dos roteiros e das pregações do padre e das freiras do bairro é difícil para a maioria dos membros das comunidades de base" (2002, p. 255). Isso pode ser ilustrado pela fala de Luiza, membro da comunidade de Brejo dos Santos, quando perguntada a respeito das atividades do grupo que fazia parte:

\footnotetext{
'Eu sei, mulher? Eu não sei responder isso.' Não satisfeita com a resposta insisti: 'Sobre o que vocês falam nas reuniões?' Ela ficou quase irritada com a minha insistência. 'Você pensa que eu sei? Que eu vou para esses cantos, eu não vejo é falar nada.' Riu um pouco, e prosseguiu: 'Fala... e.. diz que é bom pra gente...Para os direitos da mulher e, é tanta coisa e eu não [entendo]' (Theije, 2002, p. 256).
}

A dificuldade de compreensão dos argumentos e das falas por um lado, e a dificuldade de se falar a "linguagem popular" por outro, levava ao insucesso do projeto conscientizador das lideranças religiosas. Havia também casos em que pessoas e grupos não engajados na ideia de democratização da Igreja Católica compreendiam de forma diferenciada a necessidade de que os leigos deveriam ocupar os diversos espaços da vida da paróquia. Neste sentido cita a fala de Erundina, representante do Apostolado da Oração e membro de $\mathrm{CEB}$, numa reunião de todos os grupos da parte urbana da paróquia, em que afirma que "os leigos têm de se responsabilizar pela organização do religioso porque o padre é preguiçoso" (THEIJE, 2002 , p. 246).

Para Burdick não se pode perder de vista que "a preferência dos membros das CEBs por atividades eclesiais ou não eclesiais representa também uma importante tendência 
nacional” (1998, p. 20); “o modelo da CEB reforçou a associação entre Igreja Católica institucional e segmentos relativamente mais estáveis, instruídos e em melhor situação financeira da classe trabalhadora local" (Ibid, p. 21).

\section{Apontamentos sobre a questão ritual na campanha liberacionista}

O ritual é um dos fatores que tem um valor simbólico importante mesmo na campanha liberacionista, que contém um bom número de concepções racionalizantes. Assim, o ritual é considerado um importante "“veículo da mensagem”" (Theije, 2002, p. 310). Para Douglas, “enquanto animal social, o homem é um animal ritual” (1991, p. 80).

Neste sentido, Kertz (1998), fala da capacidade do ritual de construir consenso e exercer papel relevante na construção de simbolismos fundamentais para a vida das pessoas. Tanto kertz (1998), como Theije (2002) são enfáticos na assertiva de que os mesmos símbolos podem ser entendidos e colocados em prática pelas pessoas das mais diversas maneiras, assim questionam a idéia de que todo sistema de crenças e cultos tem sempre representações com "a mesma significação objetiva e desempenham por toda parte as mesmas funções" (Durkheim, 1996, p. X), não obstante suas diversidades de formas.

Geertz (1997) ao falar da importância dos símbolos na expressão do poder político, também nos dá elementos para pensarmos as práticas simbólicas na vida religiosa. As transformações nas práticas rituais arraigados na vida comunitária eram questionadas com empenho pelos fiéis. Muito disso advém do fato de que os rituais são apresentados como tendo eficácia quando realizados da forma que sempre foram e não de outra. Pois, como afirma Turner, os rituais são representados como tento eficácia, "como carregados de poder de fontes desconhecidas, e como capazes de agir sobre pessoas e grupos que entram em contato com eles de modo a mudá-los para melhor ou em direção desejada" (2005, p. 90).

Essa direção tem a ver com o contexto local e com as possibilidades e limitações que estes oferecem aos atores sociais. Assim, as práticas religiosas são relacionadas com a noção de 'fato social total' de Mauss (2003), pois exprimem de uma só vez concepções religiosas, morais, econômicas, estéticas, dentre outras, que são importantes constituintes da vida social.

Dessa forma, as possibilidades interpretativas estão relacionadas à estrutura social local com suas oportunidades e constrangimentos que medeiam a existência das idéias e as 
práticas sociais, deixando em evidência a idéia de que campanhas culturais e práticas sociais não ocorrem num vácuo, "os vínculos culturais e as oportunidades culturais influenciam a maneira como a mensagem liberacionista é recebida e retrabalhada, tanto pelos basistas quanto pelos leigos" (Theije, 2002, p. 73). Dessa forma "os leigos também estão envolvidos em expressar e retrabalhar as imagens e os valores religiosos" (Ibid, p. 74).

\section{Considerações Finais}

O texto procurou explorar alguns trabalhos a respeito das CEBs e da teologia da libertação sem a pretensão de construir uma análise conclusiva a respeito do assunto, mas que fosse capaz de nos permitir visualizar alguns elementos importantes para os resultados da campanha liberacionista, tais como o contexto local, os rituais e a pré-compreensão de mundo dos atores sociais. A diversidade de cenários pelo Brasil e a multiplicidade de resultados obtidos pela campanha cultural dificultam a construção de uma versão ampla e convincente a respeito das CEBs e da Teologia da Libertação com capacidade de oferecer formulações válidas para se ter uma visão mais generalista.

Uma proposição consolidada na literatura sobre o assunto é de que foi pequeno o número de pessoas membros das CEBs que efetivamente responderam às mensagens católicas da forma que objetivava o clero liberacionista. Entretanto, fica evidente que a literatura que trata desta temática é muito menor do que aquela que trata dos sucessos políticos e sociais dos trabalhos das CEBs. Neste sentido, pode-se dizer que as práticas liberacionistas nem sempre ocorrem da forma racional esperada pelos intelectuais e as diversas concepções católicas podem se mesclar, sendo impossível encontrar uma forma pura.

Vale destacar que o catolicismo liberacionista, além de mediado por outras práticas, também o é pelo contexto local. Assim, os constrangimentos e incentivos para a ação precisam ser considerados para não se tirar conclusões precipitadas de que as pessoas não compreenderam bem as ideias ou que a "campanha cultural" foi um fracasso, quando na verdade os cenários de dependência política e constrangimentos sociais apresentavam grande força.

INTRATEXTOS, Rio de Janeiro. vol 2, nº 1, pp 33 - 50, 2010. 
A exigência dos agentes pastorais e alguns leigos, de que as lideranças das CEBs sejam participativas e coerentes em suas práticas, leva alguns membros a se sentirem pressionados e se afastam por não se sentirem capazes de corresponder a estas expectativas. A necessidade de um pensamento coerente e racional, de acordo com os pressupostos liberacionistas, também é fator de dificuldade para a maioria dos membros. Muitas ocasiões exigiam certas habilidades dos agentes pastorais e muita disposição dos leigos, já que o processo poderia ser longo e desânimo de lado a lado pode não ter sido algo incomum.

Outro fator importante diz respeito à fala dos atores sociais. Os que tinham dificuldades de expressão oral acabavam sendo suprimidos pelos demais e acabam não se sentindo participantes ativos do grupo. Esta é uma questão tratada em diversos trabalhos a respeito das CEBs.

As mudanças muito generalizadas também sofriam grandes resistências dos fiéis católicos, sobretudo no que se refere às transformações dos ritos que estavam arraigados na memória coletiva local. Não obstante as resistências e dificuldades encontradas pelo clero liberacionista, as transformações católicas trouxeram importantes consequências sociais e políticas.

A idéia do texto foi mostrar que além das conquistas houve dificuldades, empecilhos e fracassos na trajetória das CEBs. Assim, nossa proposta foi levantar questões que incentivem pesquisas capazes de oferecer informações abrangentes das várias facetas das CEBs, de sucesso, mas também de dificuldades e fracassos.

\section{REFERÊNCIAS BIBLIOGRÁFICAS}

BEOZZO, José Oscar. A Igreja do Brasil: de João XXIII a João Paulo II, de Medellín a Santo Domingo. Petrópolis: Vozes, 1993.

BERGER, Peter L. O Dossel do Sagrado. São Paulo: Paulina, 1987.

BURDICK, John. Procurando Deus no Brasil. Petrópolis: Vozes, 1996.

CANCLINI, Nestor Garcia. Culturas Híbridas: estratégias para entrar e sair da modernidade. São Paulo: Edusp, 2006. 
DOUGLAS, Mary. Pureza e Perigo. Lisboa, Edições 70, 1991.

DURKHEIM, Émile. As formas elementares da vida religiosa: o sistema totêmico na Austrália. São Paulo; Martins Fontes, 1996.

GEERTZ, Clifford. “A religião como sistema cultural”. In: Interpretações da Cultura. Rio de Janeiro: Zahar, 1978.

"O beliscão do destino: a religião como experiência, sentido, identidade e poder". In: Nova luz sobre a antropologia. Rio de Janeiro, Zahar, 2001.

GIDDENS, Anthony. As conseqüiências da modernidade. Tradução: Raul Fiker. São Paulo: Editora UNESP, 1991.

HERVIEU-LÉGER, Daniele. O peregrino e o convertido; a religião em movimento. Lisboa Gradiva, 2006.

KERTZ, David. "The Power of Rites". In: Ritual, Politics and Power. New Haven/London, Yale University Press, 1998.

LESBAUPIN, Ivo et al.. "Revisitando as CEBs: um estudo no Rio de Janeiro e em Minas Gerais". Religião e Sociedade, 24, 1: 142-176, 2004.

LESBAUPIN, Ivo. "Comunidade de base e mudança social". Praia Vermelha - Estudo de Política e Teoria Social, 3:54-79, 2000.

LÖWY, Michael. Marxismo e Teologia da Libertação. São Paulo: Cortez, Autores Associados, 1995.

MACHADO, Maria das Dores. Carismáticos e Pentecostais. Campinas. Ed. Associados, 1996.

MAINWARING, Scott. A Igreja e a Política no Brasil (1916-1985). São Paulo: Brasiliense, 1989.

MARIZ, Cecília \& MACHADO, Maria das Dores. "Mudanças recentes no campo religioso brasileiro". Antropológica 5, 1998.

MARIZ, Cecília. Coping with Poverty. Philadelphia: Temple University Press, 1994. 
"Para além das ideologias: catolicismo e nova prática política no interior de Pernambuco”. Religião e Sociedade, Rio de Janeiro, 20 (2): 141-155, 1999.

MAUSS, Marcel. Sociologia e antropologia. São Paulo, EPU, 1974.

OLIVEIRA, Pedro A. Ribeiro de. (2001). "Perfil social e político das lideranças de CEBs no Brasil”. Memória e Caminhada, 1:6-13.

PETRINI, João Carlos. CEB's: um novo sujeito popular. Rio de Janeiro: Paz e Terra, 1984.

REGIDOR, Jose Ramos. "Vinte e Cinco anos da Teologia da Libertação". In: BOFF, Leonardo (org). A Teologia da Libertação: Balanço e Perspectivas. São Paulo: Editora Ática, 1996.

RODRIGUES, Solange dos Santos (1997). Comunidades eclesiais de base no Brasil: interfaces entre religião, política e produção do conhecimento. Rio de Janeiro: Dissertação de Mestrado em Ciências Sociais, UFRJ.

SAHLLINs, Marshall. Ilhas de História. Rio de Janeiro: Jorge Zahar, 1990.

TEIXEIRA, Faustino. Os Encontros Intereclesiais de Cebs no Brasil. São Paulo: Paulinas, 1996.

THEIJE, Marjo de \& MARIZ, Cecília. "Localizing and Globalizing in Brazil Catholicism: comparing inculturation in Liberationist and Charismatic Catholic cultures". Latin American Research Review 43 (1). 35-54, 2008.

THEIJE, Marjo de. Tudo o que é de Deus é Bom: uma antropologia do catolicismo liberacionista em Garanhuns, Brasil. Recife. Fundação Joaquim Nabuco - Editora Massangana, 2002.

TURNER, Victor. Floresta de símbolos - aspectos do ritual Ndembu. Tradução de Paulo Gabriel Hilu da Rocha Pinto. Niterói: Editora da Universidade Federal Fluminense, 2005.

WEBER, Max. "A psicologia das religiões mundiais". In: Ensaios de Sociologia. Rio de Janeiro: LTC Editora, 2002.

“As rejeições do mundo e suas direções". In: Ensaios de Sociologia. Rio de Janeiro: LTC Editora, 2002. 